\title{
Interest in technology-based and traditional smoking cessation programs among adult smokers in Ankara, Turkey
}

Michele L Ybarra ${ }^{1 *}$, A Tülay Bağci Bosi ${ }^{2}$, Nazmi Bilir ${ }^{2}$, Jodi S Holtrop ${ }^{3}$, Josephine Korchmaros ${ }^{1}$ and Salih Emri ${ }^{4}$

\begin{abstract}
Background: Little is known about the demand for smoking cessation services in settings with high smoking prevalence rates. Furthermore, acceptability of text messaging and Internet as delivery mechanisms for smoking cessation programs in non-developed countries is under-reported. Given the cost effectiveness of technologybased programs, these may be more feasible to roll out in settings with limited public health resources relative to in-person programs.

Findings: 148 adult smokers took part in a community-based survey in Ankara, Turkey. Two in five (43\%) respondents reported typically smoking their first cigarette within 30 minutes of waking. Many participants expressed a desire to quit smoking: $27 \%$ reported seriously thinking about quitting in the next 30 days; $53 \%$ reported at least one quit attempt in the past year. Two in five smokers wanting to quit reported they were somewhat or extremely like to try a smoking cessation program if it were accessible via text messaging (45\%) or online (43\%).

Conclusions: Opportunities for low-cost, high-reach, technology-based smoking cessation programs are underutilized. Findings support the development and testing of these types of interventions for adult smokers in Turkey.
\end{abstract}

Keywords: smoking cessation, Turkey, middle income country, technology-based interventions

Although smoking rates have decreased in high-income countries, rates in low- and middle-income countries seem to be resistant to declines [1]. This is especially true in Turkey, a middle income country [2] with a national population of almost 73 million people [3]. Turkey is $6^{\text {th }}$ in the world in smoking consumption [4] and is one of the top ten producers of tobacco [5]. An estimated 48\% of Turkish men and 15\% of Turkish women 15 years of age and older smoke cigarettes [5]. Indeed, a current smoker is found in seven out of 10 households [6]. Factors contributing to smoking prevalence are complex [7]. Because of the long lag time between onset of smoking and onset of disease however, cessation among current adult smokers is the path to reducing mortality within the next 25 years [8].

\footnotetext{
* Correspondence: michele@is4k.com

'Internet Solutions for Kids, Inc., 555 N. El Camino Real \#A347, San Clemente, CA 92672-6745, USA

Full list of author information is available at the end of the article
}

Implementation of effective smoking cessation programs in developing countries with high smoking prevalence rates such as Turkey is a major public health priority [5,9-11]. Even so, constrained public health resources make this difficult and literature documenting successful smoking interventions in Turkey is sparse. Demir and colleagues [12] report results of a pilot smoking cessation study conducted in an outpatient clinic where $40 \%$ of 118 patients using nicotine replacement therapy were quit at 3-months. Similarly, Emri and colleagues [13] report $46 \%$ of males and $37 \%$ of females were quit at 10 weeks using nicotine patches $(n=51)$ in their outpatient smoking cessation study. Yilmaz et al. [14] tested the effects of smoking intervention messages delivered to mothers during pediatric well-child visits on cessation $(n=363)$. Findings suggest that mothers who receive smoking intervention messages report significantly more smoking cessation or reduction behavior; this is especially true for mothers exposed to messages
C Biomed Central

(c) 2011 Ybarra et al; licensee BioMed Central Ltd. This is an Open Access article distributed under the terms of the Creative Commons Attribution License (http://creativecommons.org/licenses/by/2.0), which permits unrestricted use, distribution, and reproduction in any medium, provided the original work is properly cited. 
that focus on the health consequences for the child. No other cessation studies were found by the authors.

Smoking is culturally and socially acceptable in Turkey [15-17]. Nonetheless, there is suggestion of a strong demand to quit in some subpopulations. Unalacak and colleagues [18] report that $65 \%$ of coal workers who are smokers living in Zonguldak, Turkey want to quit and $60 \%$ reported making at least one quit attempt in the previous year. Given the lack of cessation research in Turkey, these data suggest there may be unmet demand for evidence-based smoking cessation programs among current smokers.

Technology, such as Internet and cell phone text messaging, represents a low-cost solution that overcomes many structural challenges and access issues that traditional programs have (e.g., lack of local services, transportation, competition for time otherwise spent on other activities, etc). Text messaging and Internet-based smoking cessation programs have reported promising short-term outcomes in developed countries [19,20]. Like many low and middle income countries, cell phone use has increased exponentially in Turkey. An estimated 53 million cell phones are owned in Turkey, making cell phones 2.7 times more common than land-line telephones [21]. With 27 million people online, Turkey ranks $15^{\text {th }}$ in the world in the gross number of Internet users [21]. The wide use of cell phones and Internet suggests that these technologies may be a feasible delivery method for urgently needed smoking cessation programs in the country.

Demand for smoking cessation services in Turkey is largely unknown. Furthermore, whether people who want to quit are willing to use smoking cessation services delivered through new technologies needs to be investigated. To address these gaps in knowledge, the current study aims to: 1) measure interest in smoking cessation services among current smokers; and 2) examine interest in services that are technology-based specifically, while comparing these rates to interest in traditional services.

\section{Methods}

A community-based survey of adults was conducted in Ankara, Turkey between April and July, 2008. As the capital of Turkey, Ankara is the second largest city in Turkey after Istanbul. Ankara is in the heart of the Anatolian Peninsula. As the bridge way between Asia and Europe, this peninsula is a main trading route for tobacco [22]. It is estimated that at least one smoker resides in $70 \%$ of the houses in the South-eastern Anatolian Region, which is similar to the country as a whole [6]. Forty-one percent of Ankara adults are smokers, ranked third in prevalence behind Istanbul (44\%) and Izmir (44\%) [23]. Ankara is, thus, characteristic of many cities in the Middle East with a high smoking prevalence.
The protocol was reviewed and approved by Western IRB in the United States and by Hacettepe University in Ankara, Turkey. Eligibility criteria included: being over 18 years of age, currently smoking daily, owning a cell phone and using text messaging in the past year, and informed consent. Ineligibility criteria included having a serious health condition (i.e., emphysema, heart disease, lung disease).

A research assistant went to government buildings and solicited those smoking outside to take part. Flyers also were posted in the common areas at Hacettepe University. Respondents were told that "we are designing a program to help adults quit smoking and we need your input".

To query the acceptability of technology-based smoking cessation programs, respondents were asked: "If there was a program designed to help you stop smoking that used the following medium to deliver the information to you, how likely would you be to try it?" Six mediums were asked: In person (group), Telephone (one on one), E-mail, Text (SMS) messages, Multimedia (MMS) messages, and web site. Participants answered on a 5-point scale [1 (extremely unlikely) - 5 (extremely likely)]. Respondents provided general information about their demographic characteristics and technology use. Perceptions and norms related to smoking were queried using items developed by Nierkens and colleagues (e.g., "Smoking is a waste of money") [24].

\section{Results}

Among the 165 adults who were identified as eligible, 152 adults completed the self-report survey (response rate $=$ 91\%). Among interested adults, reasons for ineligibility included: not living in Ankara, having a smoking-related chronic disease, and not seriously thinking about quitting in the next 30 days. Four respondents were deemed ineligible during data cleaning; three because they reported not owning or using a cell phone, and one because of the report of no cigarette smoking in the past seven days. Consequently, the final sample size was 148 .

Characteristics of the 148 respondents are shown in Table 1. Respondents were similar to the general population in Turkey, albeit with a slightly higher monthly income $(1,250$ - 1,999 Turkish lira) than average $(1,103$ Turkish lira) [25]. Two in five respondents (43\%) reported that they usually smoked their first cigarette within 30 minutes of waking. An important minority of respondents (27\%) reported a desire to quit in the next 30 days.

Just over half (53\%) of respondents reported a pastyear quit attempt. Although quit attempts were commonly reported, few attempters (23\%) reported using a cessation aid.

As shown in Table 2, smoking was generally viewed negatively. Only $28 \%$ of respondents indicated that they 
Table 1 Characteristics of survey respondents $(n=148)$

\begin{tabular}{|c|c|}
\hline Personal Characteristics & $\%(n)$ \\
\hline \multicolumn{2}{|l|}{ Demographic characteristics } \\
\hline Age (M: SD) range: 19-63 & $37.8(10.0)$ \\
\hline Female & $44 \%(65)$ \\
\hline Married & $64 \%(94)$ \\
\hline \multicolumn{2}{|l|}{ Household income (per month) } \\
\hline $1249 \mathrm{ytl}$ and less & $26 \%(39)$ \\
\hline $1250-1999$ ytl & $28 \%(41)$ \\
\hline $2000-4000 y \mathrm{tl}$ & $27 \%(40)$ \\
\hline More than $4000 \mathrm{ytl}$ & $17 \%(25)$ \\
\hline Missing/don't know & $2 \%(3)$ \\
\hline \multicolumn{2}{|l|}{ Technology Characteristics } \\
\hline $\begin{array}{l}\text { Send/receive text messages everyday/almost every } \\
\text { day }\end{array}$ & $43 \%(63)$ \\
\hline Use email everyday/almost everyday & $38 \%(56)$ \\
\hline $\begin{array}{l}\text { Use Internet (other than email) everyday/almost } \\
\text { everyday }\end{array}$ & $49 \%(73)$ \\
\hline \multicolumn{2}{|l|}{ Health characteristics } \\
\hline Asthma & $11 \%(16)$ \\
\hline Respiratory allergies & $10 \%(15)$ \\
\hline \multicolumn{2}{|l|}{ Smoking characteristics } \\
\hline Someone else in the household currently smoking & $8 \%(12)$ \\
\hline Family member currently smoking & $80 \%(112)$ \\
\hline Family member has quit smoking & $59 \%(88)$ \\
\hline Current smoker of narghile (water pipe) & $5 \%(7)$ \\
\hline $\begin{array}{l}\text { First cigarettes of the day within } 30 \text { minutes of } \\
\text { waking }\end{array}$ & $43 \%(63)$ \\
\hline \multicolumn{2}{|l|}{ Average number of cigarettes in a day } \\
\hline 1-5 cigarettes & $9 \%(14)$ \\
\hline 6-15 cigarettes & $43 \%(63)$ \\
\hline $16-25$ cigarettes & $38 \%(56)$ \\
\hline 26-40 cigarettes & $10 \%(14)$ \\
\hline 40 or more cigarettes per day & $<1 \%(1)$ \\
\hline \multicolumn{2}{|l|}{ Seriously thinking about quitting } \\
\hline In the next 30 days & $27 \%(40)$ \\
\hline In the next 6 months & $14 \%(20)$ \\
\hline Sometime & $39 \%(58)$ \\
\hline Never & $18 \%(26)$ \\
\hline Missing & $3 \%(4)$ \\
\hline $\begin{array}{l}\text { Average number of quit attempts for } 24 \text { hours or } \\
\text { more in the past year (M:SD) }\end{array}$ & $1.2(1.5)$ \\
\hline
\end{tabular}

agreed or strongly agreed that smoking was "normal" and only $12 \%$ agreed that it was "cool". Conversely, $77 \%$ agreed that smoking was a waste of money and $94 \%$ agreed that it was bad for one's health.

All respondents had access to each type of smoking cessation program delivery medium asked about-in-person, telephone, email, cell phone-based text messaging and multimedia messaging, and web site. Seven in ten (69\%) respondents said that they were somewhat or extremely likely to try at least one of the six quitting aids queried if they were trying to quit. Among those
Table 2 Norms for smoking $(\mathrm{n}=\mathbf{1 4 8})$

\begin{tabular}{|c|c|}
\hline $\begin{array}{l}\text { Perceptions about smoking (agree/strongly agree } \\
\text { that...) }\end{array}$ & \\
\hline \multicolumn{2}{|l|}{ Negative attitudes towards smoking } \\
\hline $\begin{array}{l}\text { Smoking is annoying for people around the } \\
\text { smoker }\end{array}$ & $94 \%(139)$ \\
\hline $\begin{array}{l}\text { Smokers are not setting a good example for their } \\
\text { children }\end{array}$ & $90 \%(133)$ \\
\hline Smoking is a waste of money & $77 \%(114)$ \\
\hline \multicolumn{2}{|l|}{$\begin{array}{l}\text { Smoking has a negative health impact on self and } \\
\text { others }\end{array}$} \\
\hline $\begin{array}{l}\text { Smoking is bad for the health of people around } \\
\text { the smoker }\end{array}$ & $94 \%(139)$ \\
\hline Smoking is bad for the smoker's health & $94 \%(139)$ \\
\hline $\begin{array}{l}\text { Smokers have a higher chance of getting lung } \\
\text { diseases }\end{array}$ & $90 \%(133)$ \\
\hline $\begin{array}{l}\text { Smokers have a higher chance of getting heart } \\
\text { diseases }\end{array}$ & $90 \%(133)$ \\
\hline Smokers cough more & $83 \%(123)$ \\
\hline \multicolumn{2}{|l|}{ Positive attitudes towards smoking } \\
\hline Smoking is normal & $28 \%(41)$ \\
\hline $\begin{array}{l}\text { Smoking is not as bad for you as they make it } \\
\text { sound }\end{array}$ & $18 \%(27)$ \\
\hline Smoking is cool & $12 \%(18)$ \\
\hline
\end{tabular}

seriously thinking about quitting in the next 30 days $(27 \%, \mathrm{n}=40)$, many indicated they would be somewhat or extremely likely to try a program if it were available in-person (63\%), via telephone (53\%), on email (51\%), via text messaging $(45 \%)$, or online $(43 \%)$ with some somewhat or extremely likely to try a program if it were available via multi-media text messaging $(20 \%$; see Table 3). Responses generally were similar for smokers who were not seriously thinking about quitting. Of exception, a greater proportion of the smokers seriously thinking about quitting (51\%) than those not seriously thinking about quitting (28\%) said they were somewhat or extremely likely to access a smoking cessation service via email $(\mathrm{p}=0.04)$.

\section{Discussion}

Despite the high smoking prevalence in Ankara, [23] a city that is characteristic of many cities in middle income countries with high smoking prevalence, [26] many respondents report a desire to quit smoking. Furthermore, contrary to previous reports of social acceptability of smoking, [24] smoking is not viewed by the smokers in the current survey as a positive behavior. This finding may be because the population surveyed is more educated than the general public. Nonetheless, it seems that there is a population of smokers who view smoking negatively and are trying to quit, albeit unsuccessfully.

Findings suggest that there is interest in cessation services among smokers. Among the most likely population 
Table 3 Likelihood of accessing a smoking cessation program based upon delivery mechanism

\begin{tabular}{|c|c|c|c|c|}
\hline & $\begin{array}{l}\text { Seriously thinking about } \\
\text { quitting in the next } 30 \text { days } \\
(n=40)\end{array}$ & $\begin{array}{l}\text { Not seriously thinking about } \\
\text { quitting in the next } 30 \text { days } \\
\text { ( } n=108)\end{array}$ & & \\
\hline Mode of intervention delivery & $\%(n)$ & $\%(n)$ & Statistical comparison & p-value \\
\hline In-person (group) & & & $\chi^{2}(5)=7.2$ & 0.21 \\
\hline Extremely Likely & $33 \%(13)$ & $15 \%(16)$ & & \\
\hline Somewhat Likely & $30 \%(12)$ & $31 \%(33)$ & & \\
\hline Neither Likely nor unlikely & $18 \%(7)$ & $19 \%(21)$ & & \\
\hline Somewhat Unlikely & $10 \%(4)$ & $18 \%(19)$ & & \\
\hline Extremely Unlikely & $10 \%(4)$ & $16 \%(17)$ & & \\
\hline Decline to answer & $0 \%(0)$ & $2 \%(2)$ & & \\
\hline Phone & & & $\chi^{2}(5)=6.9$ & 0.23 \\
\hline Extremely Likely & $25 \%(10)$ & $13 \%(14)$ & & \\
\hline Somewhat Likely & $28 \%(11)$ & $22 \%(24)$ & & \\
\hline Neither Likely nor unlikely & $20 \%(8)$ & $15 \%(16)$ & & \\
\hline Somewhat Unlikely & $15 \%(6)$ & $30 \%(32)$ & & \\
\hline Extremely Unlikely & $10 \%(4)$ & $17 \%(18)$ & & \\
\hline Decline to answer & $3 \%(1)$ & $4 \%(4)$ & & \\
\hline Email & & & $\chi^{2}(5)=11.6$ & 0.04 \\
\hline Extremely Likely & $28 \%(11)$ & $9 \%(10)$ & & \\
\hline Somewhat Likely & $23 \%(9)$ & $19 \%(20)$ & & \\
\hline Neither Likely nor unlikely & $13 \%(5)$ & $8 \%(9)$ & & \\
\hline Somewhat Unlikely & $20 \%(8)$ & $38 \%(41)$ & & \\
\hline Extremely Unlikely & $15 \%(6)$ & $19 \%(21)$ & & \\
\hline Decline to answer & $3 \%(1)$ & $6 \%(7)$ & & \\
\hline Text messaging & & & $\chi^{2}(5)=3.2$ & 0.66 \\
\hline Extremely Likely & $15 \%(6)$ & $9 \%(10)$ & & \\
\hline Somewhat Likely & $30 \%(12)$ & $22 \%(24)$ & & \\
\hline Neither Likely nor unlikely & $10 \%(4)$ & $10 \%(11)$ & & \\
\hline Somewhat Unlikely & $23 \%(9)$ & $34 \%(37)$ & & \\
\hline Extremely Unlikely & $20 \%(8)$ & $19 \%(21)$ & & \\
\hline Decline to answer & $3 \%(1)$ & $5 \%(5)$ & & \\
\hline Multi-media text messaging & & & $\chi^{2}(5)=2.6$ & 0.76 \\
\hline Extremely Likely & $5 \%(2)$ & $6 \%(6)$ & & \\
\hline Somewhat Likely & $15 \%(6)$ & $10 \%(11)$ & & \\
\hline Neither Likely nor unlikely & $5 \%(2)$ & $7 \%(8)$ & & \\
\hline Somewhat Unlikely & $35 \%(14)$ & $45 \%(49)$ & & \\
\hline Extremely Unlikely & $33 \%(13)$ & $23 \%(25)$ & & \\
\hline Decline to answer & $8 \%(3)$ & $8 \%(9)$ & & \\
\hline Internet & & & $\chi^{2}(5)=8.3$ & 0.14 \\
\hline Extremely Likely & $18 \%(7)$ & $7 \%(8)$ & & \\
\hline Somewhat Likely & $25 \%(10)$ & $18 \%(19)$ & & \\
\hline Neither Likely nor unlikely & $8 \%(3)$ & $8 \%(9)$ & & \\
\hline Somewhat Unlikely & $28 \%(11)$ & $37 \%(40)$ & & \\
\hline Extremely Unlikely & $23 \%(9)$ & $20 \%(22)$ & & \\
\hline Decline to answer & $0 \%(0)$ & $9 \%(10)$ & & \\
\hline
\end{tabular}

to access services - smokers seriously thinking about quitting in the next 30 days - the majority said they would likely use cessation services if they were available. This included both traditional and technology-based options. Traditional services such as in-person and telephone counseling engendered more interest than technology-based services among survey respondents. These services require relatively more resources however, and have limited accessibility. Indeed, Turkey's Ministry of Health has developed and is implementing a free quit line [personal communication, Emri, January, 2011]. Anecdotal accounts suggest that the infrastructure is 
insufficient to meet demand; some people are waiting over 12 minutes on hold before speaking with a health educator. Opportunities to integrate higher cost efforts (e.g., quit lines) with more cost effective methods (e.g., text messaging) might be considered by public health officials. For example, text messages could reinforce information conveyed by the telephone counselor; or smokers could use the communication tool to reach out to the counselor when in crisis. This coupling of communication methods could increase the efficiency and, therefore, capacity of the telephone quit line.

Two in five respondents seriously thinking about quitting in the next 30 days expressed interest in text messaging and Internet-based cessation services. Reviews suggest that these delivery modes can be associated with behavior change at least in the short term $[19,20]$. Interventions have been reported in New Zealand, the United States, England, and Australia. Data suggest exponential technology growth in Turkey, [21] with similar usage increases noted in other countries in the Middle East and Asia $[27,28]$ that also have high smoking prevalence. Efforts to develop and test the efficacy of text messaging and Internet-based smoking cessation services in these countries are warranted.

Multimedia text messages had the lowest rate of interest among smokers. This may be because of the associated cost to both own an MMS-capable phone, as well as to send and receive these types of messages. This is in contrast to SMS, which is free to receive. Not all technology is equal, nor is access homogenous. Researchers are encouraged to consider the target population and where they "are". While MMS may provide more flexibility in programming, it reaches fewer people. If the lure of technology is its reach, then we diminish its impact by choosing less ubiquitous platforms. This said, researchers also must try to anticipate trends and develop programs for where populations may "be" in the future given the long lag time between development and implementation.

Study limitations include self-selection bias of the convenience sample, and the small sample size. Because of recruiting respondents near government buildings and Hacettepe University, our sample might be more educated, which may be related to increased interest in technology-based interventions compared to the general smoking population. This possibility, however, is offset by the fact that participants were told that "we are designing a program to help adults quit smoking"; participants did not self-select based upon interest in technology-based programs per se. It also should be noted that intention and interest in smoking cessation services (or lack thereof) do not equal participation (or lack of participation) in these services.

\section{Conclusion}

Findings suggest that some adult smokers in Ankara may be interested in utilizing treatments to aid in cessation, including low-cost, high-reach technology-based applications such as text messaging, email, and web sites. Public health efforts should be focused on increasing the availability of and access to evidenced-based smoking cessation programs, including those that harness new technologies. As an example, these data will be used by the authors to inform the development of a text messaging-based smoking cessation program for adult smokers in Ankara.

\section{Funding}

The project described was supported by Award Number R01TW007918 from the Fogerty International Center. The content is solely the responsibility of the authors and does not necessarily represent the official views of the Fogerty International Center or the National Institutes of Health.

\section{Author details}

${ }^{1}$ Internet Solutions for Kids, Inc., 555 N. El Camino Real \#A347, San Clemente, CA 92672-6745, USA. '2Department of Public Health, Hacettepe University School of Medicine, Ankara, 06100, Turkey. ${ }^{3}$ Department of Family Medicine, Michigan State University, B101 Clinical Center, Michigan State University, East Lansing, MI 48824, USA. ${ }^{4}$ Department of Chest Diseases, Hacettepe University School of Medicine, Ankara, 06100, Turkey.

\section{Authors' contributions}

$M L Y, A T B B$, and SE made substantial contribution to the survey conception and design. ATBB and SE made substantial contribution to the acquisition of data. MLY analyzed the data and drafted the article. All authors (MLY, ATBB, $S E, N B, J S H$, and JK) made substantial contribution to the interpretation of data and revised it critically for important intellectual content. All authors read and approved the final manuscript.

\section{Competing interests}

The authors declare that they have no competing interests.

Received: 15 February 2011 Accepted: 1 August 2011

Published: 1 August 2011

\section{References}

1. Firat D: Tobacco and cancer in Turkey. J Environ Pathol Toxicol Oncol 1996, 15:155-160.

2. World Bank: World Bank list of economies (January 2011). World Bank Washington, DC; 2011 [http://data.worldbank.org/country/turkey], Accessed March 23, 2011.

3. Central Intelligence Agency: The World Factbook: Turkey. Central Intelligence Agency. Washington, DC; 2011 [https://www.cia.gov/library/ publications/the-world-factbook/geos/tu.html], Accessed March 23, 2011

4. Emri S, Bagci T, Karakoca Y: Cigarette smoking habits among primary school children in Turkey. Chest 1997, 112:863-864.

5. Yürekli A, Önder Z, Elibol M, et al: The Economics of Tobacco and Tobacco Taxation in Turkey. International Union Against Tuberculosis and Lung Disease. Paris; 2010.

6. Bozkurt Al, Sahinoz S, Ozcirpici B, et al: Patterns of active and passive smoking, and associated factors, in the South-east Anatolian Project (SEAP) region in Turkey. BMC Public Health 2006, 6:15.

7. Srinivas K, Rao B: Explaining cross-country variation in cigarette consumption. Tob Induc Dis 2009, 5:1. 
8. Doll $R$, Peto $R$, Wheatley $K$, et al: Mortality in relation to smoking: 40 years' observations on male British doctors. BMJ (Clinical Research Ed) 1994, 309:901-911.

9. Laxminarayan R, Mills AJ, Breman JG, et al: Advancement of global health: key messages from the Disease Control Priorities Project. Lancet 2006, 367:1193-1208.

10. Akala FA, El-Saharty S: Public-health challenges in the Middle East and North Africa. Lancet 2006, 367:961-964.

11. Bilir N, Guciz B, Yildiz A: Assessment of Anti-Tobacco Law in Turkey. Ankara: Hacettepe Public Health Foundation; 2003.

12. Demir T, Tutluoğlu B, Koç N, Bilgin L: One-year follow up results of Smoking Cessation Outpatient Clinic in Turkish. Tuberk Toraks 2004, 52:63-68.

13. Köksal A, Emri S, Üsküdar O: Effect of nicotine replacement therapy in quitting in a hospital base clinical of Türkiye. Eur Respir J 1999, 14:75s.

14. Yilmaz G, Karacan C, Yoney A, et al: Brief intervention on maternal smoking: A randomized controlled trial. Child Care Health Dev 2006, 32:73-79.

15. Ghouri N, Atcha M, Sheikh A: Influence of Islam on smoking among Muslims. BMJ 2006, 332:291-294.

16. Nierkens V, Stronks K, de Vries H: Attitudes, social influences and selfefficacy expectations across different motivational stages among immigrant smokers: Replication of the pattern. Prev Med 2006, 43:306-311.

17. Yuksel H, Corbett KK: Mixed messages: A qualitative study of the meanings and context of high school students' tobacco use in Turkey. Health Promot Int 2005, 20:360-366.

18. Unalacak M, Altin R, Kart L, et al: Smoking prevalence, behaviour, and nicotine addiction among coal workers in Zonguldak, Turkey. J Occup Health 2004, 46:289-295.

19. Whittaker R, Borland R, Bullen C, et al: Mobile phone-based interventions for smoking cessation. Cochrane Database Syst Rev 2009, , 4: CD006611.

20. Civljak M, Sheikh A, Stead L, et al: Internet-based interventions for smoking cessation. Cochrane Database Syst Rev 2010, , 9: CD007078.

21. Central Intelligence Agency: The World Factbook: Turkey. Central Intelligence Agency. Washington, DC; 2008 [https://www.cia.gov/library/ publications/the-world-factbook/geos/tu.html], Accessed August 8, 2008.

22. Simpson D: Turkey: Upping up the anti. Tob Control 2003, 12:245-246.

23. Emri S, Basoglu S, Turnagol H, et al: Epidemiology of smoking among Turkish adults: A national household survey, 2002. The Second International Symposium on Medical Geology, Nutrition and Cancer Istanbul; 2003.

24. Nierkens V, Stronks K, van Oel CJ, et al: Beliefs of Turkish and Moroccan immigrants in The Netherlands about smoking cessation: implications for prevention. Health Educ Res 2005, 20:622-634.

25. Turkiye Istatistik Kurumu: Tuik 2006 Kazanc Yapisi Anketi Sonuclari. Turkiye Istatistik Kurumu. Ankara; 2006 [http://www.tuik.gov.tr/PreHaberBultenleri. do?id=1999], Accessed February 15, 2011.

26. World Health Organization: WHO European Country Profiles on Tobacco Control. WHO Regional Office for Europe; 2003 [http://www.euro.who.int/ __data/assets/pdf_file/0006/68118/E80607.pdf], Assessed March 1, 2011.

27. Central Intelligence Agency: The World Factbook. Country Comparison: Telephone - Mobile Cellular. Central Intelligence Agency. Washington, DC; 2009 [https://www.cia.gov/library/publications/the-world-factbook/ rankorder/2151rank.html], Accessed February 15, 2011.

28. Central Intelligence Agency: The World Factbook. Country Comparison: Internet Users. Central Intelligence Agency. Washington, DC; 2009 [https:// www.cia.gov/library/publications/the-world-factbook/rankorder/2153rank. html], Accessed February 15, 2011.

doi:10.1186/1617-9625-9-10

Cite this article as: Ybarra et al.: Interest in technology-based and traditional smoking cessation programs among adult smokers in Ankara, Turkey. Tobacco Induced Diseases 2011 9:10.

\section{Submit your next manuscript to BioMed Central and take full advantage of:}

- Convenient online submission

- Thorough peer review

- No space constraints or color figure charges

- Immediate publication on acceptance

- Inclusion in PubMed, CAS, Scopus and Google Scholar

- Research which is freely available for redistribution

Submit your manuscript at www.biomedcentral.com/submit
Biomed Central 